\title{
Prioritizing lean manufacturing practices in small to medium enterprises by applying TOPSIS in fuzzy environment
}

\begin{abstract}
Due to the globalization most of the Small to Medium Enterprises (SMEs) are faced with a lot of pressure to survive. To overcome these pressures, Lean Production System could be very helpful to SMEs. In this research we want to highlight how it can help SMEs, identify limitations to implement lean manufacturing in SMEs and finally prioritize lean practices for implementing in SMEs. For this aim, TOPSIS method in fuzzy environment was applied. Twenty two lean practices which identified by Shah and Ward in 2003 [10] is used as the most suitable lean practices for implementing lean production. Then the barriers of implementing lean production in SMEs identified. An example is provided to illustrate finding of this study. In this study, the barriers of implementing lean production in SMEs were highlighted. It has strived to illustrate the applicability of Multi Criteria Decision Making method in lean production and SMEs. Finally, the result which is the ranked practices of lean production could help managers of SMEs to choose the most suitable practices of lean associated with less risk.
\end{abstract}

Keyword: Fuzzy TOPSIS; Lean manufacturing; Lean production in SMEs; Small to medium enterprises 